\title{
DINAMIKA POLITISASI AGAMA DI TIMUR TENGAH PRA DAN PASCA ARAB SPRING; STUDI KASUS AL IKHWAN AL MUSLIMUN DI MESIR
}

\author{
Mush'ab Muqoddas Eka Purnomo \\ $\overline{\text { Pengamat Terorisme di Timur Tengah azhary60122@gmail.com }}$
}

\section{Abstrak}

Al Ikhwan Al Muslimun menjelang dan sesudah Arab Spring mendapatkan sorotan sebagai salah satu elemen Umat Islam yang ideologi dan pemikirannya tersebar di berbagai Negara, tidak hanya di Negara Arab dan Negara Islam non Arab, akan tetapi juga di Negara Barat. Saat rezim Al Ikhwan Al Muslimun di Mesir tumbang, wajah lama Al Ikhwan Al Muslimun yang telah terpengaruh pemikiran Sayid Quthb kembali memunculkan aksi-aksi teror. Tulisan singkat ini berupaya menjelaskan pergolakan dan kegalatan pemikiran yang terjadi di dalam tubuh Al Ikhwan Al Muslimun, dari berdiri pada tahun 1928 sampai tumbang dari tampuk kekuasaan pada tahun 2013.

Kata kunci : Umat Islam, Mesir, Al Ikhwan Al Muslimun, Sayid Quthb, organisasi khusus.

Sejatinya, sistem pemerintahan yang digagas oleh para cendikiawan Islam klasik pada abad pertengahan (era Dinasti Abbasia) merupakan bagian hasil penerjemahan buku-buku pemikiran dan keilmuan termasuk di antaranya terkait sistem pemerintahan Yunani yang disempurnakan oleh Romawi. Ahmad Suhelmi (2007) mengutip Ziya Gokalp (1954), Bernard Lewis (1988) dan Nurcholis Majid (1999) menguatkan pendapat tersebut karena Islam merupakan agama inklusif sehingga mendorong pengikutnya untuk senantiasa belajar dan melestarikan peradaban di berbagai negeri sehingga perkembangan dinamika keilmuan dalam tubuh Umat Islam selalu berkembang di setiap zaman. Inklusifitas ini memberikan ruang bagi ideologi-ideologi sosial-politik dan ekonomi mewarnai dinamika politik Umat Islam di berbagai negara, terutama sistem pemerintahan berbentuk republik dengan demokrasi sebagai nilai dasar dalam trias politika. ${ }^{59}$ 
Ditegaskan bahwa, walaupun Bangsa Arab tampil sebagai pemenang secara militer, tidak lantas memberangus nilai dan warisan keilmuan budaya setempat khususnya Romawi dan Persia, akan tetapi justru melestarikan termasuk di antaranya melalui aktifitas penerjemahan termasuk, salah satu hasilnya adalah karya monumental Al Ahkam As Sulthaniyah karya Ali bin Muhammad bin Habib Al Mawardi (974-1058), seorang menteri di era Abbasia. Karya-karya terkait pemerintahan dan sejarah inilah yang kemudian banyak memberikan inspirasi bagi gerakan-gerakan yang berusaha mendirikan Negara Islam, yang dianggap sebagai dalih bahwa Negara Islam ternyata eksis dalam sejarah dan harus ditegakkan kembali.

Sementara itu, gerakan-gerakan perlawanan berbasis pemikiran keagamaan dalam sejarah Umat Islam pada era modern dimulai pada gerakan Muhammad bin Abdul Wahab (1703-1791) dari daerah Najed (bagan timur Arab Saudi) dengan dalih pemurnian akidah yang kemudian memunculkan perlawananperlawanan lainnya atas Dinasti Turki Utsmani ${ }^{60}$ di kawasan Timur Tengah pada abad ke-18 dan ke-19 antara lain Muhammad bin Ali Asy Syaukani (17601834) di Yaman, Syihabuddin Al Alusi (1721-1781) di Irak, Al Faulani (17541817) di Nigeria, Haji Syari'atullah (1764-1840) di Teluk Bangal, Muhammad bin Ali As Sanusi Al Khathabi (1787-1859) di Libya, Abdul Aziz Ad Dahlawi (1746-1824) di India, Utsman bin Qadiyuw (1754-1817) di Afrika Utara, Umar Baqir Bahbahani (1706-1790) di Karbala Irak dan kemudian berkembang di Asfahan Iran. ${ }^{61}$ Selanjutnya, gerakan-gerakan tersebut memberikan warna pada dinamika politik Umat Islam sampai saat ini dengan narasi mendirikan Negara Islam dan menegakkan Syariat Islam di berbagai negara.

\section{Dinamika Pergulatan Al Ikhwan Al Muslimun}

Al Ikhwan Al Muslimun yang didirikan pada tahun 1928 oleh Hasan Al Banna sesuai pendapat Ahmad Ban $^{62}$ (2017) sebenarnya merupakan gerakan politik untuk kembali mendirikan kembali Khilafah Islamiyah pasca tumbangnya Dinasti Turki Utsmani empat tahun sebelumnya. Cover yang digunakan adalah sebagai gerakan yang beraktifitas seperti tarekat sufi sampai pada tahun Pemilu 1938 di mana diselenggarakan Pemilu dan Hasan Al Banna yang berusaha

60 Didirikan pada tahun 1299 dan bubar pasca Perang Dunia I pada tahun 1922 dengan penguasa terakhir Abdul Hamid II. Secara fikih, Turki Utsmani bermadzhab Hanafi yang digunakan sebagai landasan hukum legislatif.

61 Muhammad Hafidz Diyab, As Salafiyun wa As Siyasah (Politik Kaum Salafi), Al Haiah Al 'Amah Al Mashriyah, Cairo, 2015, Hal. 117-118

62 Mantan anggota biro politik Al Ikhwan Al Muslimun 
memasuki Parlemen gagal dan dimenangkan oleh Partai Wafd. ${ }^{63}$ Setelah kalah Pemilu, Al Ikhwan Al Muslimun berganti menjadi gerakan perlawanan atas kolonialisme Inggris dan anti Zionisme dengan melakukan pelatihan bersenjata bagi kader-kadernya dalam cover kegiatan kepanduan, di mana hal ini kemudian menjadi awal dari dibentuknya organisasi khusus yang bertujuan melenyapkan musuh-musuh Islam, akan tetapi kemudian justru dimanfaatkan untuk melenyapkan tokoh dan pejabat pemerintahan yang dianggap sebagai musuh Al Ikhwan Al Muslimun seperti PM Mahmud Fahmi An Naqrasy (18881948). ${ }^{64}$

Al Ikhwan Al Muslimun kembali mengalami pergolakan yang sangat keras pasca Revolusi 1952 setelah pecah kongsi dengan Jamal Abdul Nasser dalam tragedi upaya pembunuhan saat Nasser berpidato di bundaran Mansyiyah Alexandria (1954) yang mengakibatkan seluruh kader Al Ikhwan Al Muslimun dipenjara termasuk di antaranya Sayid Quthb yang kecewa dengan Nasser karena tidak mendapatkan jatah sebagai menteri pendidikan. ${ }^{65}$ Kader-kader organisasi khusus Al Ikhwan Al Muslimun di antaranya Abdul Fattah Ismail ${ }^{66}$ saat dalam penjara bertemu dengan Sayid Quthb yang mendapatkan perlakuan khusus dengan dibolehkannya menulis sehingga kemudian terbitkan karya Ma'alim fii Thariq dan Tafsir Fii Dlilalil Qur'an dengan rujukan utama karya-karya Abu Al A'la Al Maududi, seorang tokoh yang kecewa dengan terpisahnya India dan Pakistan, sehingga menggagas pemikiran adanya Negara Islam dan Negara Kafir.

Syaikh Ali Jum'ah (2017) menjelaskan bahwa Sayid Quthb membagi permasalahan akidah menjadi tiga bagian yaitu Al Uluhiyah, Ar Rububiyah dan Al Hakimiyah yang sangat bertentangan dengan ajaran akidah yang dipelajari oleh Umat Islam sejak masa kecil. Pemikiran ini dikembangkan oleh Sayid Quthb yang menyebutkan setiap rezim yang bertentangan dengan pemikirannya adalah Pemerintah Kafir dan masyarakat yang menentang pemikirannya adalah Masyarakat Jahiliyah. ${ }^{67}$ Pemikiran ini kemudian menjadi landasan acuan dan penafsiran legitimasi keagamaan bagi organisasi-organisasi teroris seperti Al Qaeda dan ISIS menarget pejabat dan fasilitas pemerintahan dan juga masyarakat sipil yang tidak memiliki keterkaitan dengan kebijakan pemerintahnya.

63 Didirikan oleh tokoh pergerakan nasional Mesir bernama Saad Zaghlul pada tahun 1919

64 Politisi dari Partai Wafd berhaluan sosialis.

65 Dapat dilihat dari pengakuan rekan Sayid Quthb, Abbas Khidlr. Lihat : Jum'ah, Ali. Hikayah Al Irhab (Sejarah Terorisme). Cairo: Al Nahar. 2017. Hal 149

66 Pengusaha kapas yang dari hasil usahanya menghidupkan kembali organisasi khusus Al Ikhwan Al Muslimun termasuk mendanai pembelian bahan peledak dan mendatangkan persenjataan dari Negara Teluk untuk menggulingkan Nasser.

67 Jum'ah, Ali. OpCit 2017. Hal 166 
Muhammad Salim Al 'Awwa (2016) menyebutkan bahwa nama dan pemikiran Sayid Quthb lebih terkenal sebagai konseptor landasan pemikiran di kalangan kelompok-kelompok radikal bersenjata daripada Abu A'la Al Maududi karena Sayid Quthb merupakan orang Arab dan seorang sastrawan yang mampu menjewantahkan pemikiran dan gagasannya dengan bahasa yang mampu melahirkan rasa simpati para pembacanya. Selain itu, Sayid Quthb juga menggunakan sudut pandang kondisi sosial dan kepentingan politik dalam menulis karya-karyanya terutama tafsir fii Dzilali Al Quran, sehingga banyak diminati oleh kalangan awam khususnya kalangan muda terpelajar dan para aktifis pergerakan. Berbeda dengan karya-karya Abu A'la Al Maududi yang ditulis dengan Bahasa Urdu yang harus dterjemahkan ke dalam Bahasa Arab terlebih dahulu sehingga sulit untuk dipahami kalangan awam. ${ }^{68}$

Ahmad Salim (2014) menganalisis bahwa selain faktor adanya konflik antar generasi dan tekanan yang dihadapi di dalam penjara atas kader-kader Al Ikhwan Al Muslimun, faktor paling penting yang menyebabkan pemikiran Sayid Quthb tersebut berkembang pesat di tengah kader-kader Al Ikhwan Al Muslimun adalah karena lemahnya pondasi keagamaan dan pemikiran kaderkader Al Ikhwan Al Muslimun, akibat lebih banyak beraktifitas di kegiatan sosial dan terutama di bidang politik. Yusuf Al Qaradhawi dalam biografinya mengakui bahwa kelemahan besar dari Al Ikhwan Al Muslimun adalah lemahnya kegiatan kebudayaan serta kajian keilmuan dan pemikiran. Selain itu, banyaknya kader-kader Al Ikhwan Al Muslimun yang berlatarbelakang dari lulusan pendidikan non-keagamaan sehingga sulit menyaring pemikiran dan pandangan Sayid Quthb. Seperti contoh adalah Mursyid Am Al Ikhwan Al Muslimun Muhammad Badie yang merupakan lulusan dari fakultas kedokteran hewan dan Presiden Muhammad Mursi merupakan lulusan dari fakultas teknik Universitas Cairo. ${ }^{69}$

Pemikiran Sayid Quthb ini kemudian menginspirasi kader-kader muda Al Ikhwan Al Muslimun di antaranya Najih Ibrahim, ${ }^{70}$ Aiman Zawahiri ${ }^{71}$ dan Karam Zuhdi mendirikan Al Jama'ah Al Islamiyah, sebuah organisasi kelompok perlawanan bersenjata atas rezim Presiden Anwar Sadat yang telah menandatangani perjanjian damai dengan Israel. As'ad Sa'id Ali (2014) menyebutkan bahwa gagasan dan pemikiran serta nilai-nilai perjuangan $\mathrm{Al}$

68 Al 'Awwa, Muhammad Salim. Al Madaris Al Fikriyah Al Islamiyah (Kelompok Pemikiran Islam). Beirut: Arab Network for Research and Publishing. 2016. Hal. 86-87

69 Salim, Ahmad. Ikhtilaf Al Islamiyin (Konflik Kaum Islamis). Beirut: Nama Center. 2015. Hal 474-476

70 Pendiri Al Jama'ah Al Islamiyah Mesir

71 Amir Al Qaeda menggantikan Osama bin Laden sejak tahun 2011 
Jama'ah Al Islamiyah di Mesir menjadi inspirasi bagi seluruh organisasi dan kelompok berbagai negara yang menginginkan penegakan Syariat Islam dan mendirikan Negara Islam dengan jalan perjuangan bersenjata. ${ }^{72}$

Pada saat yang bersamaan, kader-kader Al Ikhwan Al Muslimun yang bereksodus ke Negara Teluk (khususnya Arab Saudi, Qatar dan Kuwait) terpengaruh dengan paham Wahabisme, dan pada dekade 1970an, seperti pengakuan Abdul Mun'im Abu Al Futuh, ${ }^{73}$ terjadi perubahan materi kaderisasi dari bukubuku yang bernuansa tasawuf seperti Al Hikam dan Ihya 'Ulumuddin menjadi buku-buku bernuansa Salafi/ Wahabi seperti Zad Al Mi'ad dan Subulus Salam yang dibagi secara gratis dan langsung berasal dari Arab Saudi. ${ }^{74}$ Selain itu, eksodus ini juga memberikan pengaruh bagi Kaum Salafi dengan adanya faksi baru bernama Salafi Sururi yang digagas oleh Muhammad Surur bin Zainul Abidin ${ }^{75}$ dan mendapatkan pertentangan dari tokoh-tokoh Salafi di antaranya Muqbil bin Hadi. ${ }^{76}$ Salafi Sururi memiliki pemikiran dan semangat melawan pemerintah serta tersebar di berbagai negara antara lain Mesir, Kuwait, Yaman dan Aljazair, sehingga dianggap akan membahayakan eksistensi rezim Arab Saudi dan Negara Teluk lainnya. ${ }^{77}$

John Louis Esposito (2002) menyebutkan bahwa Arab Saudi turut berperan penting dalam mendanai penyebaran paham-paham keislaman yang digagas oleh Hasan Al Banna, Sayid Quthb dan Abu Al A'la Al Maududi pada dekade 1960an dengan tujuan membendung pengaruh Pan-arabisme dan Nasseris yang mengancam eksistensi Arab Saudi, Negara Teluk dan Negara Arab yang bersistem monarki. Buku-buku Hasan Al Banna, Sayid Quthb dan Abu A'la Al Maududi diterjemahkan ke berbagai bahasa dan disebarkan ke berbagai negara. Tidak hanya itu gagasan dan pemikiran tiga tokoh tersebut oleh kader-kader Al Ikhwan Al Muslimun yang mendapatkan suaka politik di Arab Saudi terutama Muhammad Quthb, saudara Sayid Quthb dikembangkan dalam berbagai

72 Ali, As'ad Said. Al Qaeda. Yogyakarta: LkiS. 2014. Hal. 27

73 Mantan anggota Maktab Irsyad Al Ikhwan Al Muslimun sampai dikeluarkan pada tahun 2006, setelah melepas jabatan sebagai sekretaris jendral Persatuan Dokter Arab. Pada tahun 2012 maju sebagai calon presiden dari jalur independen akan tetapi gagal,kemudian pada tahun 2013 mendirikan Partai Misr Qaweya. Pada tahun 2018, setelah kembali dari London Inggris ditangkap oleh Aparat Keamanan karena kepemilikan senjata ilegal perkebunannya yang berada di perbatasan provinsi Alexandria.

74 Tamam, Husam. Abdul Mun'im Abu Al Futuh (Biografi). Cairo: Dar Asy Syuruq. 2012. Hal. 68

75 Mantan perwira dinas intelijen militer Angkatan Bersenjata Suriah, dan bergabung dengan Al Ikhwan Al Muslimun karena kecewa dengan Presiden Suriah Hafidz Al Asad.

76 Tokoh Salafi asal Yaman yang bermukim di Arab Saudi dan memiliki murid dari berbagai Negara antara lain Mustafa Al Adawi asal Mesir dan Ja'far Umar Thalib asal Indonesia.

77 As Suwaidi, Jamal Sanad. As Sarrab (Fatamorgana). Abu Dhabi: Emirates for Strategies Studies dan Resaerch Center. 2015. Hal 421-460. 
buku. ${ }^{78}$ Pemaparan Muhammad Hafidz Diyab (2015) membenarkan hal tersebut. Arab Saudi melakukan ekspansi penyebaran paham Salafi/ Wahabi (dengan cover islamisasi ilmu pengetahuan) ke berbagai negara sebagai upaya untuk menjadikan Arab Saudi sebagai pusat wacana keislaman di era modern, melalui pembentukan berbagai pusat studi, pusat kajian, lembaga pendidikan dan yayasan sosial di berbagai negara khususnya Negara Islam non-Arab. ${ }^{79}$

\section{Nalar Penggunaan Narasi Keagamaan Dalam Dinamika Internal Al Ikhwan Al Muslimun}

Pengaruh organisasi khusus dalam tubuh Al Ikhwan Al Muslimun semakin menguat pasca wafatnya Mursyid Am Al Ikhwan Al Muslimun Ma'mun Al Hudlaibi dan naiknya Mustafa Masyhur pada tahun 1996 yang kembali menghidupkan jaringan internasional Al Ikhwan Al Muslimun di berbagai belahan dunia pada dekade 1980an, dan mengakarnya seluruh kader organisasi khusus di seluruh struktur Al Ikhwan Al Muslimun sampai tingkat distrik. Ahmad Ban (2017) menilai dengan pengaruh organisasi khusus tersebut, hirarki organisasi Al Ikhwan Al Muslimun menjadi tidak teratur, karena setelah tahun 2000, pihak yang seharusnya mengadakan pertemuan untuk evaluasi sesuai AD/ART adalah majelis syuro sampai tingkat distrik, akan tetapi pada kenyataannya adalah pengurus eksekutif yang seharusnya dievaluasi. Biro yang dikuasai oleh organisasi khusus adalah biro tarbiyah yang dapat diumpamakan sebagai 'filter' agar struktur kepengurusan organisasi Al Ikhwan Al Muslimun khususnya di pos-pos penting terutama pos biro tarbiyah tidak diisi oleh kaderkader yang berhaluan moderat. ${ }^{80}$

Sementara itu, guna menyingkarkan kader-kader yang kritis dan berhaluan moderat, kader-kader organisasi khusus menggunakan narasi-narasi propaganda bahwa kader-kader barhaluan moderat tidak taat beribadah dan memiliki citra buruk di depan publik, seperti kasus yang menimpa Abdul Mun'im Abu Al Futuh pada tahun 2006 dan Muhammad Al Biltaji saat akan mencalonkan sebagai ketua dewan pengurus Fredom and Justice Party tingkat provinsi Cairo. Kader-kader organisasi khusus semakin menguasai struktur keorganisasian Al Ikhwan Al Muslimun setelah kongres 2009 yang mendudukkan Muhammad

78 Esposito, John Louis (Penj. Arif Maftuhin). Unholy War. Yogyakarta: LkiS. 2002. Hal . 131-132

79 Diyab, Muhammad Hafidz. As Salafiyun wa As Siyasah (Politik Kaum Salafi). Cairo: Al Haiah Al 'Amah Al Mashriyah. 2015. Hal. 147-148

80 Ban, Ahmad. Ikhwan wa Salafiyun wa Dawa'isy (Al Ikhwan Al Muslimun, Salafi dan ISIS). Cairo: Al Mahrusah Center. 2017. Hal 35-40 
Badie $^{81}$ sebagai mursyid am, akan tetapi di bawah bayang-bayang wakilnya, Muhammad Khairat Asy Syathir, ${ }^{82}$ yang memegang kendali organisasi khusus.

\section{Narasi Politik Al Ikhwan Al Muslimun Dalam Mencapai Dan Mempertahankan Kekuasaan}

Guna memperbaiki citra Al Ikhwan Al Muslimun pasca kasus Salsabil (1993. 1998), kader-kader Al Ikhwan Al Muslimun seperti Abdul Mun'im Abu Al Futuh, Muhammad Habib ${ }^{83}$ dan Muhammad Salim Al Awwa mengadakan berbagai kegiatan berupa diskusi dn forum budaya terkait kondisi sosial-politik sehingga kemudian Al Ikhwan Al Muslimun kembali ikut dalam kontestasi politik pada tahun 2004, sehingga memenangkan 80 kursi di Parlemen. Selanjutnya, guna menggalang kekuatan-kekuatan politik sipil lainnya, Al Ikhwan Al Muslimun menggunakan narasi-narasi demokrasi seperti kebebasan berpendapat, partisipasi perempuan dan Umat Kristiani serta jargon antikorupsi. ${ }^{84}$ Jargon dan narasi tersebut menjadi modal penting bagi Al Ikhwan Al Muslimun dalam memenangkan Pileg 2011 dan Pilpres 2012 yang mengusung Muhammad Mursi, ketua Fredom and Justice Party (FJP).

Menjelang Pileg yang digelar pada Desember 2011 dan sampai Januari 2012, pada Juni 2011, FJP menggalang dukungan dari elemen-elemen liberal dan sosialis untuk membentuk Aliansi Demokrasi yang terdiri dari sebelas partai di antaranya FJP, Partai An-Nur, ${ }^{85}$ Partai Amal Al Islami, Partai Karamah ${ }^{86}$ dan Partai Wafd dengan tujuan untuk menghalangi kroni rezim Presiden Husni Mubarak yang ingin kembali menguasai panggung politik. Pada perjalanannya, pada Oktober 2011 Partai Wafd keluar dari Aliansi Demokrasi karena FJP dianggap melanggar kesepakatan terkait jatah caleg yang akan diajukan.

Hasil Pileg kemudian didominasi oleh FJP yang menguasai 123 kursi disusul Partai An-Nur sebanyak 38 kursi dan kemudian Aliansi Egyptin Block ${ }^{87}$

81 Bergabung dengan organisasi khusus pada dekade 1960an dan termasuk di antara mahasiswa yang ditahan dan dipenjara bersama Sayid Quthb di dalam Penjara Militer, dan diintrogasi oleh Kejaksaan.

82 Bergabung dengan organisasi khusus pada dekade 1960an dan pada tahun 1993 terlibat kasus spionase dalam cover perusahaan Salsabil yang bergerak pada penjualan alat-alat elektronik seperti komputer, handy talky dan pesawat kamera drone serta program-program komputer. Setelah kasus tersebut, Kejaksaan Militer mengeluarkan peraturan No. 3 Tahun 1998 bahwa setiap pihak yang

83 Mantan Wakil Mursyid Am I (orang kedua di dalam struktur Al Ikhwan Al Muslimun) akan tetapi disingkirkan pada tahun 2006.

84 Tamam, Husam. OpCit, Hal. 127-132

85 Beraliran Salafi dan merupakan kepanjangan dari kepentingan Arab Saudi di Mesir.

86 Beraliran Nasseris (ideologi sosialis dan Pan-arabisme yang digagas oleh Jama Abdul Nasser).

87 Digagas Egyptian Fredom Party yang dibesut oleh pengusaha bernama Naguib Sawiris (orang terkaya keempat di Timur Tengah) dengan menggalang dukungan elemen-elemen liberal-nasionalis. 
sebanyak 34 kursi. Selanjutnya, posisi ketua DPR diduduki oleh sekjend FPJ Saad Al Katatni. Sedangkan hasil pemilihan MPR kembali dimenangkan oleh FJP yang memperoleh 105 kursi, disusul Partai An-Nur 45 kursi, Partai Wafd 14 kursi, Egyptian Block delapan kursi. Adapun ketua MPR diduduki oleh Ahmad Fahmi dari FJP.

Kemenangan FJP mendorong Al Ikhwan Al Muslimun untuk mengajukan calon presiden, yaitu Muhammad Khairat Asy Syathir dan ketua FJP Muhammad Mursi sebagai cadangan. Sayangnya, kemudian KPU mendiskualifikasi Muhammad Khairat Asy Syathir karena kasus Salsabil dan meloloskan Muhammad Mursi sebagai calon presiden. Figur lain dari kalangan kader Al Ikhwan Al Muslimun yang juga lolos kualifikasi adalah Abdul Mun'im Abu Al Futuh dan Muhammad Salim Al 'Awwa. Pemungutan suara putaran pertama yang berlangsung pada 23-24 Mei 2012 dimenangkan oleh Muhammad Mursi (24,78 \%) dan Ahmad Syafiq ${ }^{88}$ (23.66 \%).

Menjelang putaran kedua yang digelar pada 16-17 Juni 2012, FJP kembali merapatkan barisan dengan elemen-elemen liberal-nasionalis termasuk di antaranya Partai Wafd dan Partai An-Nur dengan narasi politik tidak memberikan peluang kembalinya sisa rezim Presiden Husni Mubarak yang direpresentasikan oleh Ahmad Syafiq. Konsolidasi politik ini memberikan masukan suara yang cukup signifikan dari elemen-elemen libral-nasionalis dan masyarakat umum yang tidak menginginkan rezim Presiden Husni Mubarak kembali berkuasa sehingga Al Ikhwan Al Muslimun melalui calonnya yaitu Muhammad Mursi memenangkap Pilpres dengan presentase 51,73 \% suara sah mengalahkan Ahmad Syafiq. ${ }^{89}$

Sedangkan kepada basis Kaum Islamis (Salafi, Al Jama'ah Al Islamiyah dan Jihadis), Al Ikhwan Al Muslimun menggunakan narasi dengan jargon bahwa Muhammad Mursi adalah calon khalifah Umat Islam yang beraliran Sunni, sehingga harus didukung, sebagai bagian dari upaya untuk menegakkan Syari'at Islam serta menjadi jalan untuk mendirikan Negara Islam dan langkah pertama menegakkan kembali Khilafah Islamiyah di muka bumi. Narasi bahwa Presiden Muhammad Mursi adalah Khalifah Islam yang harus dilindungi, kembali digunakan untuk menjaga kekuasaan rezim Al Ikhwan Al Muslimun yang diperoleh dari cara yang demokratis, sehingga sulit untuk dikritik. ${ }^{90}$

\footnotetext{
88 Merupakan pensiunan perwira tinggi AU Mesir dengan pangkat terakhir marsekal madya dengan jabatan terakhir kepala staf Angkatan Udara dan setelah pensiun menjabat sebagai menteri penerbangan sipil. Saat Revolusi 25 Januari 2011 meledak, diangkat sebagai perdana menteri, akan tetapi gagal membentuk kabinet.

89 Salim, Ahmad. OpCit, Hal. 140-141

90 Ban, Ahmad. OpCit, Hal. 206-207
} 
Al Ikhwan Al Muslimun kemudian memperkuat kekuasaannya ke berbagai lini dan instansi pemerintahan dengen mengangkat kader-kadernya di pospos staretgis bahkan memecat pejabat-pejabat yang dianggap sebagai ancaman. Tiga pejabat penting yang dipecat adalah Jendral Besar Muhammad Husain Thanthawi dari jabatan menteri pertahanan, Letnan Jendral Sami Anan dari jabatan kepala staf Angkatan Perang dan Mayor Jendral Murad Muwafi dari jabatan kepala dinas intelijen, pasca serangan yang dilakukan oleh sayap Al Qaeda di Semenanjung Sinai Mesir yaitu Anshar Bait Al Maqdis ${ }^{11}$ atas salah satu pos Angkatan Bersenjata Mesir di Rafah (perbatasan Mesir-Israel) pada Agustus 2012 yang mengakibatkan belasan personalia Angkatan Bersenjata Mesir tewas.

Faktor krusial lainnya yang mendorong dukungan kalangan nasionalis dan liberal marah dengan rezim Al Ikhwan Al Muslimun dan kaum islamis adalah dipaksakannya perubahan amandemen konstitusi yang mencantumkan Pasal 219 sebagai penafsiran dari Pasal 2 terkait dasar hukum dan legislasi yaitu nilai Syari'at Islam adalah kitab-kitab mu'tabarah (rujukan terkenal) yang memberikan peluang bagi buku-buku radikal sebagai rujukan dasar legislasi dan kebijakan negara. Pasal 219 ini kemudian dihapus oleh konstituante pasca tumbangnya rezim Al Ikhwan Al Muslimun dan kewenangan penafsiran Pasal 2 hanya diberkan kepada Mahkamah Konstitusi dengan keharusan berkonsultasi kepada Badan Ulama Senior Al Azhar, sebagai lembaga tertinggi institusi keagamaan di Mesir.

Adapun faktor luar negeri yang mendorong institusi kenegaraan khususnya Angkatan Bersenjata Mesir tidak menginginkan agar rezim Al Ikhwan Al Muslimun berlangsung lama adalah rencana keinginan Al Ikhwan Al Muslimun menjalin hubungan dengan Iran, setelah Presiden Iran Mahmud Ahmadinejad dalam sambutannya di KTT OKI pada Februari 2011 bahwa Iran mampu melindungi Mesir, sangat mengusik kedaulatan dan kehormatan Mesir, sebagai negara berdaulat. Pernyataan tersebut dianggap sebagai bentuk pelecehan dan upaya intervensi urusan dalam negeri Mesir, sehingga Angkatan Bersenjata Mesir menyatakan penolakan terhadap penandatanganan MoU peningkatan hubungan dan kerjasama yang ditandatangani oleh Muhammad Mursi dan Mahmud Ahmadinejad. ${ }^{92}$

91 Merupakan wajah baru dari Tauhid wa Jihad yang didirikan pada tahun 2005 dan melancarkan aksi-aksi teror atas Apart dan destinasi wisata di provinsi Sinai Selatan. Pada November 2014 menyatakan bergabung dengan ISIS dan berpisah dari Al Qaeda, tanpa konflik karena memiliki musuh bersama yaitu Angkatan Bersenjata Mesir yang tengah melancarkan operasi militer di Semenanjung Sinai.

92 Bakri, Mustafa. As Sisi (Biografi). Cairo: Dar Al Mishriyah Al Libnaniyah. 2014. Hal. 18-19. 


\section{Tumbangnya Rezim Al Ikhwan Al Muslimun}

Pada 30 Juni 2013 massa dari berbagai elemen berkumpul di Bundaran Tahrir, depan gedung Kementerian Pertahanan dan Istana Kepresidenan Al Ittihadia menuntut agar rezim Al Ikhwan Al Muslimun ditumbangkan. Aksi demonstrasi tersebut dijawab oleh Menteri Pertahanan Jendral Abdul Fattah As Sisi dengan seruan musyawararah nasional seluruh elemen politik dalam jangka waktu 48 jam.

Selanjutnya, pada 3 Juli 2013, Menhan Jendral Abdul Fattah As Sisi merepresentasikan seluruh elemen politik dan institusi negara menyampaikan maklumat bahwa ketua Mahkamah Konstitusi yang saat itu dijabat oleh Adly Mansour dilantik sebagai pejabat presiden sampai dilaksanakan pemilihan. Turut hadir dalam penyampaian makluat tersebut adalah Grand Syaikh Al Azhar Prof. Dr. Ahmad Ath Thayib, Pemimpin Gereja Koptik Paus Tawadlrus II, Ketua Partai Dostor Muhammad Al Baradei, Ketua Partai Wafd Sayid Badawi, Penggagas Gerakan Tamarod/ Rebel Mahmud Badar dan Mendagri Inspektur Jendral Polisi Muhammad Ibrahim.

Tidak ingin kalah, Al Ikhwan Al Muslimun menggelar demonstrasi tandingan di Bundaran Rabea Al Adawea ${ }^{93}$ dan Bundaran An Nahdlah ${ }^{94}$ dalam bentuk demo sit in yang berlangsung selama 50 hari dari 20 Juni 2013 sampai dibubarkan pada 14 Agustus 2013, dengan paksa setelah negosiasi yang berlangsung selama dua jam tidak diindahkan. Sementara itu, Presiden Muhammad Mursi dinyatakan sebagai tahanan rumah oleh Angkatan Bersenjata Mesir, karena terkait berbagai kasus kriminal. ${ }^{95}$

\section{Narasi Dan Dinamika Perlawanan Al Ikhwan Al Muslimun Pasca Revolusi 30 Juni 2013}

Mantan Ketua Dewan Syuro Al Jama'ah Al Islamiyah Mesir Najih Ibrahim mengatakan pada demo sit in tersebut keluar berbagai kalimat ungkapan takfir yang ditujukan kepada lawan-lawan politik Al Ikhwan Al Muslimun, bahwa perjuangan mempertahankan rezim Al Ikhwan Al Muslimun adalah perjuangan mempertahankan agama Islam dan semua pihak yang menggulingkan Muhammad Mursi dan Al Ikhwan Al Muslimun dari tampuk kekuasaan telah

93 Berada di distrik Nasr City provinsi Cairo dan di bagian selatan kawasan area gedung dinas intelijen militer Angkatan Bersenjata Mesir.

94 Berada di distrik Giza City provinsi Giza di depan Universitas Cairo.

95 Beberapa kasus penting yang menjerat Muhammad Mursi dan tokoh Al Ikhwan Al Muslimun lainnya adalah kasus kabur dari penjara pada saat gejolak Revolusi 25 Januari 2011, spionase Qatar, spionase dengan Hamas dan kasus kerusuhan insiden di sekitar Istana Kepresidenan Al Ittihadiyah pada Desember 2012. 
keluar dari agama Islam. Tidak hanya itu, Dosen Sejarah Islam Universitas Ummul Qura Makkah Arab Saudi Jamal Abdul Hadi menyampaikan mimpinya bahwa Malaikat Jibril AS berada bersama massa demo sit in di Bundaran Rabea dan Baginda Nabi Muhammad SAW mempersilahkan Muhammad Mursi untuk mengimami shalat berjamaah. ${ }^{96}$ Narasi-narasi seperti ini yang kemudian dianggap sebagai landasan keagamaan bahwa perjuangan perlawanan kaderkader Al Ikhwan Al Muslimun dalam bentuk aksi-aksi demonstrasi dan perlawanan bersenjata mendapatkan restu dan diridloi oleh Allah SWT.

Perlawanan terhadap Pemerintah Mesir kemudian tidak menjadikan Al Ikhwan Al Muslimun solid, akan tetapi justru terpecah dalam berbagai faksi. Ahmad Ban (2017) menjabarkan peta konflik internal Al Ikhwan Al Muslimun setelah tumbang di tahun 2013 terbagi menjadi tiga faksi besar yaitu :

1. Faksi reformis dengan tokoh Abdul Mun'im Abu Al Futuh dan anggotaanggota kultural Al Ikhwan Al Muslimun.

2. Faksi konservatif yang berisikan para pimpinan Al Ikhwan Al Muslimun yang sebagian besar berada di dalam penjara atau kabur ke luar Mesir (Turki dan Qatar).

3. Faksil radikal yang dipimpin oleh Anggota Maktab Irsyad Al Ikhwan Al Muslimun Muhammad Muhammad Kamaluddin yang menguasai empat kepengurusan wilayah antara lain Cairo, Alexandria, Tengah Delta Nil dan Bagian Utara Mesir Selatan, yang merupakan basis-basis kuat Al Ikhwan Al Muslimun. Muhammad Muhammad Kamaluddin bersama kalangan pemuda Al Ikhwan Al Muslimun membentuk biro krisis yang berdalih membina dan menyantuni keluarga anggota Al Ikhwan Al Muslimun yang ditahan Aparat Kepolisian, akan tetapi Aparat Kepolisian berhasil mengungkap biro krisis tersebut yang diketahui mengendalikan seluruh aksi-aksi teror atas aparat dan fasilitas publik melalui kelompok-kelompok bersenjata dengan berbagai nama antara lain Kataib Helwan Al Musallahah (Brigade Helwan Bersenjata), Muqawamah Asy Sya'biyah Giza (Perlawanan Rakyat Giza), Liwa Ats Tsaurah (Panji Revolusi) dan Harakah Sawa'id Misr (Gerakan Penolong Mesir).

4. Faksi diaspora dengan nama biro diaspora Al Ikhwan Al Muslimun di luar negeri yang dipimpin oleh Ahmad Abdur Rahman yang berusaha memutus koneksi faksi konservatif dengan jaringan internasional Al Ikhwan Al Muslimun dengan cara membentuk berbagai channel TV, akan tetapi tidak berkembang karena kekurangan dana. ${ }^{97}$

96 Harfi, Suzan. Nidham Al Khash (Sistem Khusus). Cairo: Mieret. 2017. Hal. 341-346

97 Ahmad Ban, OpCit, Hal 265-268 
Najih Ibrahim (2016) sebagai seorang senior dari Kaum Islamis di Mesir mempertanyakan jatuhnya korban dari kalangan aparat dan rakyat sipil bahkan wisatawan asing tidak memiliki kaitan dengan dinamika politik dan tidak memiliki kepentingan politik di Mesir, tewas, sebagai korban aksi-aksi teror yang dilakukan oleh seluruh elemen-elemen radikal kelompok-kelompok Islamis di Mesir (Al Ikhwan Al Muslimun, Al Jama'ah Al Islamiyah dan Salafi) yang hanya memiliki dendam politik sehingga buta mata hatinya dan tidak memilah target aksi-aksi terornya. Setahun semenjak tumbangnya rezim Al Ikhwan Al Muslimun saja, setidaknya terapat aksi-aksi teror berskala besar dan memiliki dampak besar seperti serangan atas Mapolres Kardasah bagian barat provinsi Giza, ledakan atas Mapolda Cairo dan Mapolda Dakahlia dan serangan atas rombongan turis asal Korea Selatan pada Februari 2014 saat berada di kota Taba dalam perjalanan menuju Al Quds. ${ }^{98}$

Adapun upaya revisi dan moderasi pemikiran kader-kader Al Ikhwan Al Muslimun yang telah ditahan oleh aparat keamanan, seperti yang berhasil dilakukan atas kader dan pimpinan Al Jama'ah Al Islamiyah pada dekade 1990an sulit untuk diterapkan karena kader-kader Al Ikhwan Al Muslimun telah didoktrin sebagai penjaga agama Islam. ${ }^{99}$ Upaya ini diketahui dipimpin oleh dosen Universitas Al Azhar Dr. Usamah Sayid Mahmud ${ }^{100}$ serta dibantu oleh Najih Ibrahim dan kader-kadernya dari Al Jama'ah Al Islamiyah yang masih memegang teguh prakarsa revisi pemikiran dan anti kekerasan. ${ }^{101}$

\section{Kesimpulan}

Haedar Nashir (2010) sejak tahun 2006 dengan tegas mengingatkan bahwa setiap partai politik termasuk yang menggunakan Islam sebagai asas secara organisasi, bertujuan untuk merebut kekuasaan bahkan dengan melakukan infiltrasi ke lahan-lahan organisasi Islam lainnya. Perebutan dan mempertahankan kekuasaan tersebut dianggap sebagai perjuangan hidup dan mati sebagai bagian dari jihad, dalam pandangan integralisme Islam yang digagas oleh Hasan Al Banna, Abu A’la Al Maududi dan Sayid Quthb. ${ }^{102}$

98 Ibrahim, Najih (Penj. Mush'ab Muqoddas Eka Purnomo). Khathru Ahlam Baghdadi (Bahaya Mimpi Al Baghdadi). Yogyakarya. Reviva Cendekia. 2016. Hal. 34-35.

99 Ibid, Hal. 276

100 Merupakan penasehat Mufti untuk urusan luar negeri kemudian diangkat sebagai penasehat kepresidenan urusan keagamaan pada tahun 2015.

101 Revisi pemikiran dan anti kekerasan Al Jama'ah Al Islamiyah digagas oleh Najih Ibrahim, Karam Zuhdi dan Muhammad Al Amin pada tahun 1995 serta didukung oleh Kepala Bidang Keagamaan Kementerian Dalam= =Negeri Mesir Inspaktur Jendral Polisi Ahmad Raafat, wartawan senior Makram Muhammad Ahmad dan pemikir Muhammad Salim Al 'Awwa

102 Nashir, Haedar. Manifestasi Gerakan Tarbiyah Bagaimana Sikap Muhammadiyah ?. Yogyakarta: Suara Muhammadiyah. 2010. Hal. 60-62. 
Ahmad Syafi'i Ma'arif (2018) mengingatkan bahwa peradaban dan dinamika politik Umat Islam di Timur Tengah tengah memasuki titik nadir karena narasi yang ditanamkan kepada kader-kader kaum islamis di Timur Tengah adalah bahwa lawan politik telah keluar dari agama Islam. Pandangan ini akan semakin parah jika menjadi pegangan oleh Umat Islam non Arab yang masih banyak tidak mampu untuk mempelajari Al Quran dan As Sunnah serta literatur keilmuan Islam yang berbahasa Arab secara langsung, dan hanya ikut-ikutan dengan pergerakan dan narasi-narasi kebencian kelompok-kelompok Islamis di Timur Tengah. ${ }^{103}$

\section{Daftar Pustaka}

Al 'Awwa, Muhammad Salim. Al Madaris Al Fikriyah Al Islamiyah (Kelompok Pemikiran Islam). Beirut: Arab Network for Research and Publishing. 2016.

Ali, As'ad Said. Al Qaeda. Yogyakarta: LkiS. 2014

As Suwaidi, Jamal Sanad. As Sarrab (Fatamorgana). Abu Dhabi: Emirates for Strategies Studies dan Resaerch Center. 2015.

Bakri, Mustafa. As Sisi (Biografi). Cairo: Dar Al Mashriyah Al Libnaniyah. 2014.

Ban, Ahmad. Ikhwan wa Salafiyun wa Dawa'isy (Al Ikhwan Al Muslimun, Salafi dan ISIS). Cairo: Al Mahrusah Center. 2017.

Diyab, Muhammad Hafidz. As Salafiyun wa As Siyasah (Politik Kaum Salafi). Cairo: Al Haiah Al 'Amah Al Mashriyah. 2015.

Esposito, John Louis (Penj. Arif Maftuhin). Unholy War. Yogyakarta: LkiS. 2002.

Harfi, Suzan. Nidham Al Khash (Sistem Khusus). Cairo: Mieret. 2017.

Ibrahim, Najih (Penj. Mush'ab Muqoddas Eka Purnomo). Khathru Ahlam Al Baghdadi (Bahaya Mimpi Al Baghdadi). Yogyakarta: Reviva Cendekia. 2016.

Jum'ah, Ali. Hikayah Al Irhab (Sejarah Terorisme). Cairo: Al Nahar. 2017.

Maarif, Ahmad Syafii. Krisis Arab dan Masa Depan Dunia Islam. Jakarta: Maarif Indtitute. 2018.

Nashir, Haedar. Manifestasi Gerakan Tarbiyah Bagaimana Sikap Muhammadiyah?. Yogyakarta: Suara Muhammadiyah. 2010.

Salim, Ahmad. Ikhtilaf Al Islamiyin (Konflik Kaum Islamis). Beirut: Nama Center. 2015.

Suhelmi, Ahmad. Pemikiran Politik Barat. Jakarta: Gramedia. 2007.

Tamam, Husam. Abdul Mun'im Abu Al Futuh (Biografi). Cairo: Dar Asy Syuruq. 2012.

103 Maarif, Ahmad Syafii. Krisis Arab dan Masa Depan Dunia Islam. Jakarta: Maarif Indtitute. 2018. Hal. 63-63 